\title{
Consumer Choices Can Reduce Packaging Waste 1
}

Kenneth R. Berger ${ }^{2}$

Did you know that up to one out of every $\$ 11$ you spend at the store pays for packaging? Also, when all packaging is accounted for, it adds up to about one-third of all the trash that's thrown away in the United States.

Industry and business are responsible for most of this waste, but consumer product packaging accounts for about 15 percent of what's discarded. When you purchase a frozen dinner, you are paying for not only the meal but for the outer paperboard box, the plastic or foil tray that holds the meal, and the covering over the food.

You pay again for packaging, directly or indirectly, when your garbage is picked up and disposed of in a landfill or incinerator. Some communities are moving toward "pay-as-you-throw" fees for every bag put out at the curb, so it makes sense to reduce household waste. Composting, recycling, and reusing items all help. And by shopping carefully you can reduce excess packaging that you would throw away.

\section{Benefits of Packaging}

Not all packaging is wasteful or undesirable. Packaging protects food products from contamination and spoilage. It protects products from damage during shipping. Packaging also provides detailed product information. Some products need packaging that is tamper-evident and child-resistant.

Many manufacturers are now putting products into redesigned or "smarter" packaging. For example, one company is marketing silicone sealant with a hole in the bottom of the tube, so it can easily be hung on a display rack. Many brands of deodorants are being sold without any paperboard box, secondary packaging, around them.

Detergents and fabric softeners are available in "ultra" or concentrated forms. These smaller containers mean that fewer materials are needed for the container itself and for shipping it. Some companies have developed programs for reusing shipping materials like foam "peanuts" and wooden pallets. Inflated polyethylene bladders altogether replace foam or cushion packaging. Others are switching to packing materials like shredded newspaper, which can be recycled or composted.

\section{Shopping Strategies}

Manufacturers are responding to pressures to reduce packaging or make a product more "environmentally-friendly," but you still pay for packaging every time you purchase a product. If this

1. This document is ABE328, one of a series of the Agricultural and Biological Engineering Department, Florida Cooperative Extension Service, Institute of Food and Agricultural Sciences, University of Florida. First published September 2002. Please visit the EDIS Web site at http://edis.ifas.ufl.edu.

2. Kenneth R. Berger, assistant professor and Extension Agricultural Safety Specialist; Agricultural and Biological Engineering Department, Institute of Food and Agricultural Sciences, University of Florida, Gainesville.

The Institute of Food and Agricultural Sciences is an equal opportunity/affirmative action employer authorized to provide research, educational information and other services only to individuals and institutions that function without regard to race, color, sex, age, handicap, or national origin. For information on obtaining other extension publications, contact your county Cooperative Extension Service office. Florida Cooperative Extension Service/Institute of Food and Agricultural Sciences/University of Florida/Christine Taylor Waddill, Dean. 
concerns you, there are ways you can reduce costs and waste.

Not every strategy will fit every lifestyle, but you should be able to find one or more ideas to use from the following suggestions. Keep track of what you save each time by making smart packaging choices when you shop. It may not seem like much at first, but within several months you'll see a difference.

When practical, buy in bulk. Large families or high product consumption levels support buying in bulk when practical. Products packaged in bulk produce less packaging waste. For example, 48 ounces of applesauce can be purchased in a large glass jar. Or, you can buy individual four-ounce containers packaged in plastic cups with foil lids that come in packages of six. You pay nearly twice the price for the same weight when you buy the individually wrapped product. However, a single person household may have less spoiled food when food purchases are in single-serve packages. Your needs and lifestyle dictate the choice -- your choice.

Choose reusable or recyclable packages. Be familiar with your community's recycling program, and pick products with containers that can be recycled. Let's consider coffee as an example. If you buy 13 ounces of coffee in a metal can, you can recycle the container and possibly the plastic lid. Or, you can buy about 7 ounces of coffee individually wrapped in a disposable coffee filter, which is then packed inside another container. Even if you include the cost of filters with the cost of coffee in the metal can, you are paying about 70 percent more for the single-serve coffee packages. Some may be willing to pay more for convenience or may prefer the product quality found in one package form over another. Again, your knowledgeable choice should guide your purchase decisions.

Avoid excessive packaging. You can pay up to 45 percent more when you buy a product, like fruit or vegetables, that has already been cut up, packaged on a plastic tray, and then shrink-wrapped. Buying the whole fruit or vegetable is cheaper, and you come home with less packaging to throw away.

Pay for the product, not the package. A conventional tube of toothpaste produces about 70 percent less waste by volume, and about 60 percent less waste by weight, than a pump-type toothpaste container. The cost is about the same for both products, but you get nearly 2 ounces more toothpaste in the conventional tube compared to the pump. In the case of the pump, you pay extra for a more attractive container and more convenient or cleaner dispensing of the product.

\section{Your Own Smart Shopping Strategies}

Sometimes you are willing to pay more for choice or convenience. For example, you may want variety, instead of one food item. You may not store large quantities of food because you could choose not to use it all before it spoiled. You may need food in smaller, safely packaged quantities for school lunches. But you can check your grocery list before you shop to make smart packaging choices.

Look for items you can buy as concentrates or "refills." Fabric softener is a good example. If you already have a plastic container for liquid fabric softener, buy a refill container at the store and then reuse the original container.

Consider buying products that don't take much time to separate into smaller servings. If you buy a box of instant pudding, you can quickly prepare and divide it into single snack servings that can be carried for lunches in reusable plastic containers. The instant pudding is less expensive than the pre-made snack packs. And, you are throwing away less packaging--about 90 percent less by volume and nearly 75 percent less by weight.

You might like the non-breakable plastic ketchup bottle, but most of the time, the plastic bottle is made of multiple or composite materials that cannot be recycled. An alternative is to purchase one bottle of ketchup in the plastic container, then refill it with ketchup from glass containers, which can be recycled.

Instead of "paper or plastic," use a canvas shopping tote or string bag. Or, if you've been saving bags, bring your own to the store, including the small plastic ones you can use for loose produce. Don't forget to bring back extra paper and plastic bags to 
your supermarket. Many stores will recycle both the plastic and paper bags that are returned by customers. Or use the plastic and paper bags at home; don't just throw them away.

\section{Summary}

You are paying for both the product you buy and the package it comes in. Then you pay either directly or indirectly to dispose of that package in a landfill or incinerator.

Packaging has benefits to the consumer--it provides product safety, informs about product use, and safeguards the product during transportation and delivery. Manufacturers are designing "smarter" packaging today. Packaging may be eliminated from some products altogether, made lighter, made to be reused or recycled, or made for multiple uses or refills.

When you shop, you can use strategies to reduce unwanted packaging. You can buy products in large sizes or in bulk quantities. You can select products with packaging that can be recycled in your community program or reused. You can purchase products that don't have excessive packaging and get more of the product for the price you pay. And you can "personalize" smart shopping strategies to your own lifestyle and family needs. Shopping with packaging options in mind can make a difference at the landfill and at the check-out counter.

\section{References}

Frank Ackerman. "Analyzing The True Costs of Packaging." BioCycle, April, 1993: 68 - 70.

David Allaway. "Does Source Reduction Work?" Resource Recycling, July, 1992: 52, 54 - 61.

Ellen Z. Harrison and R. J. Angell. Waste Prevention Tool Kit For Local Governments. Cornell Waste Management Institute, Ithaca, N.Y., December, 1992.

Jeff Lederman and L. Yount. "Quantifying Packaging Waste At Grocery Stores." Resource Recycling, December, 1992: 43 - 45.
Stuart Leavenworth. "Rethinking Recycling." The News and Observer, Raleigh, N.C., February 13, 1994: 1, 6A.

Paul J. Ligon. "Isolating The Cost of Excess Packaging." BioCycle, November, 1991: 68 - 70.

"Packaging in the 90's." Garbage, December/January, 1993: 24 - 31.

Sandra A. Zaslow, W. S. Hammett and J. H. Lloyd. "Master Waste Manager." North Carolina Cooperative Extension Service, Raleigh, N.C., 1992.

"Packaging Choices that Reduce Waste" North Carolina Cooperative Extension Service as publication fcs-421 (June 1994) Prepared by Dr. Sandra A. Zaslow 